\title{
Index of Kindling References
}

\author{
Compiled by: JUHN A. WADA, M.D.
}
(A) HISTORICAL
(B) GENERAL BACKGROUND
(C) ELECTRICAL KINDLING
(D) RELATED STUDIES
(E) CHEMICAL KINDLING
(F) ELECTROPHYSIOLOGY
(G) CHEMISTRY AND PHARMACOLOGY
(H) BEHAVIOR AND LEARNING
(I) CLINICAL IMPLICATION

\section{(A) HISTORICAL}

ALONSO-DE FLORIDA, F. and DELGADO, J. M. R. (1958). Lasting Behavioral and EEG Changes in Cats Induced by Prolonged Stimulation of Amygdala. American Journal of Physiology, 193: 223-229.

DELGADO, J. M. R. (1959). Prolonged Stimulation of Brain in Awake Monkeys. Journal of Neurophysiology, 22: 458-475.

DELGADO, J. M. R. and SEVILLANO, M. (1961), Evolution of Repeated Hippocampal Seizure in the Cat. Electroenceph. Clin. Neurophysiol. 13: 722-733.

ESSIG, C. F., GROCE, M. E. and WILLIAMSON, E. L. (1961). Reversible Elevation of Electroconvulsive Threshold and Occurrence of Spontaneous Convulsions Upon Repeated Electrical Stimulation of the Cat Brain. Experimental Neurol. 4: 37-47.

GODDARD, G. V. (1967). Development of Epileptic Seizures Through Brain Stimulation at Low Intensity. Nature, 214: 1020-1021.

WATANABE, E. (1936). Experimental Study on Pathogenesis of Epileptic Convulsive Seizure (Japanese). Psychiatria et Neurologica Japonica, 40: 1-36.

\section{(B) GENERAL BACKGROUND}

AYALA, G. F., DICHTER, M., GUMNIT, R. J., MATSUMOTO, H. and SPENCER, W. A. (1973). Genesis of Epileptic Interictal Spikes. New Knowledge of Cortical Feedback Systems Suggest a Neurophysiological Explanation of Brief Paroxysms. Brain Research, 12: 1-17.

ECCLES, J. C. (1953). The Neurophysiological Basis of Mind. p. 314, Oxford, Clarendon Press.

GAITO, J. (1974). The Kindling Effect. Physiological Psychology. Vol. 2, No. I, 45-50.
GODDARD, G. V. (1972). Prologue. In The Neurobiology of the Amygdala, (Ed.) Eleftheriou, B.E., p. 581-596, Plenum Publishing Corporation, New York.

HEBB, D. O. (1949). The Organization of Behavior, a Neuropsychological Theory. John Wiley \& Sons, New York.

HUGHES, J. R. (1958). Post-Tetanic Potentiation. Physiological Review, 38: 91-113.

JASPER, H. (1969). Mechanism of Propagation: Extracellular Studies. In: Basic Mechanism of the Epilepsies. (Ed.) Jasper, H., Ward, A. and Pope, A. p. 421-438, Little, Brown, Boston.

LASHLEY, K. S. (1950). In Search of the Engram. Society of Experimental Biology Symposium No. 4. Physiological Mechanisms in Animal Behavior. Cambridge University Press, 454-482.

MORRELL, F. (1959/60). Secondary Epileptogenci Lesions. Epilepsia. 1: 538-560.

MORRELL, F. (1969). Physiology and Histochemistry of The Mirror Focus. Basic Mechanisms of the Epilepsies, (Ed.) Jasper, H., Ward, A. and Pope, A. p. 357-374. Little, Brown, Boston.

PURPURA, D. P., PENRY, J. K., TOWER, D. B., WOODBURY, D. M. and WALTER, R. D. (eds.) (1972). Experimental Models of Epilepsy. Raven Press, New York.

SATO, M. and WADA, J. A. (1975). Review on the Kindling Preparation: A New Experimental Model of Epilepsy (Japanese). Brain and Nerve, 27: 257-276.

WADA, J. A. and CORNELIUS, L. R. (1960). Functional Alteration of Deep Structures in Cats with Chronic Focus Cortical Irritative Lesions. A.M.A. Archives of Neurology, 3: 425-447.

WADA, J. A. (1964). Longitudinal Analysis of Chronic Epileptogenic Brain Process. Epileptology, (Ed.) Wada, T. p. 426-453. Igakushoin, Tokyo.

WILDER, B. J. (1972). Projection Phenomena and Secondary Epileptogenesis - Mirror Foci. Experimental Models of Epilepsy. (Eds.) Purpura, D., Jasper, H., Tower, D., Woodbury, D. M. and Walter, R., 85: 111.

\section{(C) ELECTRICAL KINDLING}

BURNHAM, (This issue). Primary and Transfer Seizure Development in the Kindled Rat. Canadian Journal of Neurological Sciences.

CORCORAN, M. E., URSTAD, H., MCCAUGHRAN, J. A. and WADA, J. A. (This issue). Frontal Lobe and Kindling in the Rat. Canadian Journal of Neurological Sciences.
CORCORAN, M. E., McCAUGHRAN, J. A. and WADA, J. A. (1973). Acute Antiepileptic Effects of Delta-9 Tetrahydrocannabinol in Rats with Kindled Seizures. Experimental Neurology, 40: 471-483.

CULLEN, N. and GODDARD, G. V. (In press.) Kindling in the Hypothalamus and Transfer to the Ipsilateral Amygdala. Behavioral Biology.

GODDARD, G. V. (1972). Long-term Alteration Following Amygdaloid Stimulation. The Neurobiology of the Amygdala. (Ed.) Eleftheriou, B. Plenum Press, New York. 581-596.

GODDARD, G. V. and McINTYRE, D. C. (1973). Some Properties of a Lasting Epileptogenic Trace Kindled by Repeated Electrical Stimulation of the Amygdala in Mammals. Surgical Approaches in Psychiatry, MTP, Lancaster. 109-115.

GODDARD, G. V.. McINTYRE, D. C. and LEECH, C. K. (1969). A Permanent Change in Brain Function Resulting from Daily Electrical Stimulation. Experimental Neurology, 25: 295-330.

KARAMYSHEV, V. D. Effect of Repeated Daily Electrical Stimulation on Seizure Activity in the Rabbit Limbic System. Translated from Neirofiziologiya, Vol. 6, No. 1. pp. 26-36, January-February 1974, 1975 Plenum Publishing Corporation, New York, N.Y.

MADRYGA, F. J., GODDARD. G. V. and RASMUSSON, D. D. (In press). The Kindling of Motor Seizures from Hippocampal Commissure in the Rat. Physiological Psychology.

McCAUGHRAN, J. A., CORCORAN, M. E. and WADA, J. A. (In press). Development of Kindled Amygdaloid Seizures After Section of the Forebrain Commissure in Rats. Folia Psychiatria et Neurologica Japonica.

McINTYRE, D. C. (This issue). Split Brain Rat: Transfer and Interference of Kindled Amygdaloid Convulsion. Canadian Journal of Neurological Sciences.

MCINTYRE, D. C. and GODDARD, G. V. (1973). Transfer. Interference and Spontaneous Recovery of Convulsions Kindled from the Rat Amygdala. Electroencephalography and Clinical Neurophysiology, 35: 533-543.

MORRELL, F. (1973). Goddard's Kindling Phenomenon: A New Model of the "Mirror Focus". Chemical Modulation of Brain Function, (Ed.) Sabelli, H.C., Raven Press. New York. 207-223.

NAKASHIMA. T.. ONISHI. T. and SATO. M. (1975). Anygdaloid and Hippocampal 
Discharge and Sleep-Arousal Levels in the Kindled Cat Preparations (Japanese). Japanese Journal of the Neurosciences Research Association, I. 16-17.

PINEL, J. P. J., PHILLIPS, A. G. and DEOL, G. (1974). Effects of Current Intensity on Kindled Motor Seizure Activity. Behavioral Biology, 11: 59-68.

PINEL, J. P. J., MUCHA, R. F. and PHILLIPS, A. G. (In press). Spontaneous Seizures Generated in Rats by Kindling: A Preliminary Report. Physiological Psychology.

RACINE, R. J. Modification of Seizure Activity by Electrical Stimulation: I. Afterdischarge Threshold. Electroencephalography and Clinical Neurophysiology.

RACINE, R. J. (1972). Modification of Seizure Activity by Electrical Stimulation: II. Motor Seizure. Electroencephalography and Clinical Neurophysiology, 32: 281-294.

RACINE. R. J.. OKUJAVA, V. and CHIPASHVILI, S. (1972). Modification of Seizure Activity by Electrical Stimulation: III. Mechanisms. Electroencephalography and Clinical Neurophysiology, 32: 295-299.

RACINE, R. J., BURNHAM, W. and GARTNER, J. (1973). First Trial Motor Seizures Triggered by Amygdaloid Stimulation in the Ratt. Electroencephalography and Clinical Neurophysiology, 35: 487-494.

RACINE, R. J., BURNHAM, W., GARTNER. J. and LEVITAN, D. (1973). Rates of Motor Seizure Development in Rats Subjected to Electrical Brain Stimulation, Strain and Interstimulation Interval Effects. Electroencephalography and Clinical Neurophysiology. 35: 553-556.

RACINE, R. J. (1975). Modification of Seizure Activity by Electrical Stimulation: Cortical Areas. Electroencephalography and Clinical Neurophysiology, 38: 1-12.

SATO, M. (In press). An Experimental Study of Epilepsy with "Kindling Effect" Procedure - I. Behavioral and Electroencephalographic Study on the Development Process of Hippocampal Seizure (Japanese). (1975). Psychiatria et Neurologia Japonica, 77

SATO, M. (In press). An Experimental Study of Epilepsy with "Kindling Effect" Procedure - II. Study on the Secondary Epileptogenesis of Hippocampal Seizure with "Transference Phenomenon" (Japanese). Psychiatria et Neurologia Japonica. 77 (1975).

SATO, M., ONISHI, T., NAKASHIMA, T., UEFUJI, K., TAKAHASHI, Y. and OTSUKI, S. (1974). Influence of Sleep Arousal Levels on the Hippocampal Interictal Discharge (Japanese). Medicine and Biology, 89: 251-256.

SATO, M.. NAKASHIMA. T., OTSUKI. S., KISHIKAWA, $H$. and KOBAYASHI, K. (In press). Change in Brain Catecholamine Levels in the Kindling Preparation of Cats (Japanese). Igakuno Ayumi, 92.

SATO, M. (1975). Hippocampal Seizure and Secondary Epileptogenesis. Folia Psychiatria et Neurologia Japonica, 75. (In press).
SATO, M. and NAKASHIMA. T. (In press). Kindling. Secondary Epileptogenesis. Sleep and Catecholamines. Canadian Journal of Neurological Sciences.

TANAKA. A. (1972). Progressive Changes of Behavioral and Electroencephalographic Responses to Daily Amygdaloid Stimulation in Rabbits. Fukuoka Medical Journal, 63: $152-164$

TANAKA, T. and NAQUET, R. (In press). Kindling Effect and Sleep Organization in Cats. Electroencephalography and Clinical Neurophysiology.

TANAKA, T., LANGE, $H$. and NAQUET, R. Sleep, Subcortical Stimulation and Kindling in the Cat.

WADA. J. A. and SATO, M. (1974). Generalized Convulsive Seizure Induced by Daily Electrical Stimulation of the Amygdala in Cats: Correlative Electrographic and Behavioral Features. Neurology, 24: 565-574.

WADA, J. A., SATO, M. and CORCORAN. M. E. (1974). Persistent Seizure Susceptibility and Recurrent Spontaneous Seizures in Kindled Cats. Epilepsia. 15: 465-478.

WADA, J. A. and SATO, M. (In press). The Generalized Convulsive Seizure State $\ln$ duced by Daily Electrical Stimulation of the Amygdala in Split Brain Cats. Epilepsia.

WADA, J. A. and SATO, M. (In press). The Generalized Convulsive Seizure State Induced by Daily Electrical Stimulation of the Amygdala in Split Brain Cats.

WADA. J. A.. SATO, M. and McCAUGHRAN. J. A. (In press). Cortical Electrographic Correlates of Convulsive Seizure Development Induced by Daily Electrical Stimulation of the Amygdala. Folia Psychiatrica et Neurologica Japonica.

WADA. J. A. and SATO. M. (In press). Effects of Unilateral Lesion in the Midbrain Reticular Formation upon Kindled Amygdaloidconvulsion in Cats. Epilepsia.

WADA, J. A. and OSAWA, T. (In press). Generalized Convulsive Seizure State Induced by Daily Electrical Amygdaloid Stimulation in Senegalese Baboons, Papio papio. Neurology.

WADA. J. A.. OSAWA, T, and MIZOGUCHI. T. (This issue). Recurrent Spontaneous Seizure State Induced by Prefron(a) Kindling in Senegalese Baboons. Papio papio. Canadian Journal of Neurological Sciences.

WADA, J.A., OSAWA, T. and McCAUGHRAN, J. A. (In press). Electrocorti Ographic Correlates of Amygdaloid Seizure Development in Rats and Cats. Folia Psychiatria et Neurologica Japonica.

WAKE, A. and WADA, J. A. (This issue). Frontal Lobe and Kindling in the Cat. Canadian Journal of Neurological Sciences.

ZAIDE. J. (1974). Differences Between Tryon Bright and Dull Rats in Seizure Activity Evoked by Amygdala Stimulation. Physiology and Behavior. Vol. 12, pp. 527-534.
(D) RELATED STUDIES

BABINGTON, R. G. and WEDEKING, P. W. (1975). Blockade of Tardive Seizures in Rats by Electroconvulsive Shock. Brain Research, 88: 141-144.

DELGADO, J. M. R., JOHNSTON, V. S., WALLACE, J. D. and BRADLEY, R. J. (1970). Operant Conditioning of Amygdala Spindling in the Free Chimpanzee, Brain Research, 22: 347-362.

DELGADO, J. M. R., RIVERA, M. L. and MIR, D. (1971). Repeated Stimulation of Amygdala in Awake Monkeys. Brain Research, 27: 111-131.

HERBERG L. J., TRESS, K. H. and BLUNDELL, J. R. (1969). Raising the Threshold in Experimental Epilepsy by Hypothalamic and Septal Stimulation and by Audiogenic Seizures. Brain, 92: 313-328.

HERBERG, L. J. and WATKINS, P. J. (1966) Epileptiform Seizures Induced by Hypothalamic Stimulation in the Rat: Resistance to Fits Following Fits. Nature, 209: 515-516.

KOVAKS, D. A. and ZOLL, J. G. (1974). Seizure Inhibition by Median Raphe Nucleus Stimulation in Rat. Brain Research, 70: 165-169.

PINEL, J. P. J., PHILLIPS, A. G. and MacNEILL, B. (1973). Blockage of highlystable "Kindled" Seizures in Rats by An tecedent Footshock. Epilepsia, 14: 29-37.

TRESS, K. J. and HERBERG, L. J. (1972). Permanent Reduction in Seizure Threshold Resulting from Repeated Electrical Stimulation. Experimental Neurology, 37: 347-359.

ROBINSON, N., DUNCAN, P. GEHRT, M., SANCES, A. and EVANS, S. (1975). Histochemistry of Trauma After Electrode Implantation and Stimulation in the Hippocampus. Archives of Neurology, Vol. 32. p. 98-102. Feb. 1975.

ST, LAURENT, J. BOGACE, J. and OLDS, J. (1965). Stimulation and Epileptiform Activity. Electroencephalography and Clinical Neurophysiology, 19: 75-87.

FONBERG, R. and DELGADO, J. M. R. (1961). Avoidance and Alimentary Reactions During Amygdaloid Stimulation. Journal of Neurophysiology, 24: 651-664.

\section{(E) CHEMICAL KINDLING}

BELLUZZI, J. D. and GROSSMAN, S. P. (1969). Avoidance Learning: Longlasting deficits after Temporal Lobe Seizures. Science, 66: 1435-1437.

GODDARD, G. V. (1969). Analysis of Avoidance Conditioning following Cholinergic Stimulation of Amygdala in Rats. Journal of Comparative and Physiological Psychology, 62: 2 pt. 2, 1-18.

GROSSMAN, S. P. (1963). Chemically Induced Epileptiform Seizures in the Cat. Science, 142: 409-411.

MASON, C. R. and COOPER, R. M. (1972). A Permanent Change in Convulsive Threshold in Normal and Brain-Damaged 
Rats with Repeated Small Doses of Pentylenetetrazol. Epilepsia, 13: 663-674.

POST, R. M. and KOPANDA, R. T Cocaine, Kindling and Reverse Tolerance. The Lancet, Feb. 15, 1975. 409-410.

POST, R. M. and KOPANDA, R. T. (In press). Progressive Behavioral Changes During Chronic Lidocaine Administration: Relationship to Kindling. Life Sciences.

VOSU, H. and WISE, R. A. (1975). Cholinergic Seizure Kindling in the Rat: Comparison of Cuadate, Amygdala and Hippocampus. Behavioral Biology, 13: 491-495.

WADA, J. A. (In press). Progressive Seizure Recruitment in Subhuman Primates and Effect of Cerebellar Stimulation upon Developed vs. Developing Amygdaloid Seizures. Escobar, A. (Ed.) Tenth Anniversary Symposium of Mexican National Institute of Neurology.

\section{(F) ELECTROPHYSIOLOGY}

BLISS, T. and GARDNER-MEDWIN, A. (1973). Long-Lasting Potentiation of Synaptic Transmission in the Dentate Area of the Unanesthetized Rabbit Following Stimulation of the Perforant Path. Journal of Physiology, 232: 357-374.

BLISS, T. and L $\varnothing \mathrm{MO}, \mathrm{T}$. (1973). LongLasting Potentiation of Synaptic Transmission in the Dentate Area of the Anesthetized Rabbit Following Stimulation of the Perforant Path. Journal of Physiology, 232: $311-356$

BRAZIER, M. A. B. (1972). Spread of Seizure Discharges in Epilepsy. Anatomical and Electrophysiological Considerations. Experimental Neurology, 36: 263-272.

BRAZIER, M. A. B. (1972). The Human Amygdala: Electrophysiological Studies. The Neurobiology of the Amygdala, (Ed.) Eleftheriou, B.A., 397-420, New York.

DOUGLAS, R. M. and GODDARD, G. V. (1975). Long-Term Potentiation of the Perforant Pathgranule Cell Synapse in the Rat Hippocampus. Brain Research, 86: 205-215.

GERSCH, W. and GODDARD, G. V. (1970). Epileptic Focus Location: Spectral Analysis Method. Science, 169: 701-702.

GLOOR, P. (1955). Electrophysiological Studies on the Corrections of the Amygdaloid Nucleus in the Cat. Part 1: The Neuronal Organization of the Amygdaloid Projection System. Electroencephalography and Clinical Neurophysiology, 7 223-242.

GODDARD, G. V. and DOUGLAS, R. N. (This issue). Is the Engram of Kindling Model the Engram of Long-Term Memory? Canadian Journal of Neurological Sciences.

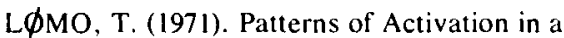
Monosynaptic Cortical Pathway: The Perforant Path Input to the Dentate Area of the Hippocampal Formation. Experimental Brain Research, 12: 18-45.

RACINE, R. J., GARTNER, J. and BURNHAM, W. M. (1972). Epileptiform Activ- ity and Neural Plasticity in Limbic Structures. Brain Research, 47: 262-268.

RACINE, R. J., NEWBERRY, F. and BURNHAM, W. (In press). PostActivation Potentiation and the Kindling Phenomenon. Electroencephalography and Clinical Neurophysiology, 39: (1975).

RACINE, R. J., TUFF, L. and ZAIDE, J. (This issue). Kindling, Unit Discharge Patterns and Neural Plasticity. Canadian Journal of Neurological Sciences.

\section{(G) CHEMISTRY AND PHARMACOLOGY}

ARNOLD, P., RACINE, R. and WISE, R. (1973). Effect of Atropine, Reserpine, 6-OHDA and Handling on Seizure Development in the Rat. Experimental Neurology, 40: 457-470.

BABINGTON, R. G. and WEDEKING, P. W. (1973). The Pharmacology of Seizures Induced by Sensitization with Low Intensity Brain Stimulation. Pharmacology Biochemistry and Behavior, Vol. 1, pp 461-467.

CORCORAN, M. E., FIBIGER, H. C., McGEER, E. G. and WADA, J. A. Potentiation of Leptazol Seizures by 6-Hydroxydopamine. Journal of Pharmacology and Pharmacy, 25: 497-499.

CORCORAN, M. E., McCOUGHRAN, J. A. and WADA, J. A. (1973). Acute Antiepileptic Effects of delta-9 Tetrahydrocannabinol in Rats with Kindled Seizures. Experimental Neurology, 40: 471-483.

CORCORAN, M. E., FIBIGER, H. C., McCAUGHRAN, J. A. and WADA, J. A. (1974). Potentiation of Amygdaloid Kindling and Metrazol-Induced Seizures by 6-Hydroxydopamine in Rats. Experimental Neurology, 45: 118-133.

FRIED, P. A. and McINTYRE, D. C. (1973). Electrical and Behavioral Attenuation of the Anti-Convulsant Properties of Delta-9THC following Chronic Administrations. Psychopharmacologia, 31: 215-227.

GAITO, J. and GAITO, S. T. (1974). Interanimal Negative Transfer of the Kindling Effect. Physiological Psychology 2 (3A) 379-382.

GAITO, J. and HOPKINS, R. W. (1973). Interanimal Transfer and Chemical Events Underlying the Kindling Effect. Bulletin Psychon. Society I (5A), 319-321.

GUNNE, L. M. and REIS, D. J. (1963). Changes in Brain Catecholamines Associates with Electrical Stimulation of Amygdaloid Nucleus. Life Sciences 11: 804-809.

MORRELL, F., TSURU, N., HOEPPNER, T. J., MORGAN, D. and HARRISON, W. H. (This issue). Secondary Epileptogenesis in Frog Forebrain: Effect of Inhibition of Protein Synthesis. Canadian Journal of Neurological Sciences.

PINEL, J. P. J., VAN OOT, P. H. and MUCHA, R. F. (1975). Intensification of the Alcohol Withdrawal Syndrome by Repeated Brain Stimulation. Nature, 254: 510.
PINEL, J. P. J. (1974). Discussant of a Paper by Frank Seixas, Predicators of Alcoholism: Prevention. Proceedings of Symposium on Biomedical Research in Alcohol Abuse Problems. Non-Medical Use of Drugs Directorate, National Health and Welfare, Halifax.

RACINE, R. J., LIVINGSTON, K. and JOAQUIN, A. (1975). Effects of Procaine HCL, Daizepam and Diphenylhydantoin on cortical Structures. Electroencephalography and Clinical Neurophysiology, 38: 355-365.

SATO, $M$. and NAKASHIMA, T. (This issue). Kindling: Secondary Epileptogenesis, Sleep and Catecholamine. Canadian Journal of Neurological Sciences.

WADA, J. A., SATO, M. and CORCORAN, M. E. (1973). Antiepileptic Properties of Delta-9 Tetrahydrocannabinol. Experimental Neurology, 39: 157-165.

WADA, J. A., OSAWA, T. and CORCORAN, M. E. (In Press). Effects of Tetrahydrocannabinols in Kindled Seizures and Photogenic Seizures in Senegalese Baboons, Papio papio, Epilepsia.

WADA, J. A., OSAWA, T., WAKE, A. and CURCORAN, M. E. (In press). Effects of Taurine on Kindled Amygdaloid Seizures in Rats. Cats and Photosensitive Baboons. Epilepsia.

WADA, J. A., WAKE, A., SATO, M. and CORCORAN, M. E. (In press). Antiepileptic and Prophylactic Effects of Tetrahydrocannabinols in Amygdaloid Kindled Cats. Epilepsia.

WADA, J. A., SATO, M., GREEN, J. and TROUPIN, A. S. (In press). Prophylactic Effects of Dilantin, Phenobarbital and Carbamazepine Examined in Kindling Cat Preparations. Archives of Neurology.

WADA, J. A., SATO, M. and CORCORAN, M. E. (1973). Antiepileptic Properties of Delta-9 Tetrahydrocannabinol. Experimental Neurology, 39: 157-165.

WISE, R. A. and CHINERMAN, J. (1974). Effects of Diazepam and Phenobarbital on Electrically-Induced Amygdaloid Seizures and Seizure Development. Experimental Neurology, 45: 355-363.

(H) BEHAVIOR AND LEARNING

ADAMEC, R. (In press). Naturally Occurring Physiological, Differences in the Limbic Systems of Killer and Non-Killer Cats. Aggressive Behavior, 1975.

ADAMEC, R. (This issue). Behavioral and Epileptic Determinants of Predatory Attack Behavior in the Cat. Canadian Journal of Neurological Sciences.

BOGACZ, J., ST. LAURENT, J. and OLDS, J. (1965). Dissociation of Self-Stimulation and Epileptiform Activitiy. Electroencephalography and Clinical Neurophysiology, 19: $75-87$

FONBERG, E. and DELGADO, J. M. R (1961). Avoidance and Alimentary Reactions During Amygdaloid Stimulation. Journal of Neurophysiology, 24: 651-664. 
GODDARD, G. V. (1964). Amgdaloid Stimulation and Learning in the Rat. Journal of Comparative and Physiological Psychology, 58: 23-30.

GODDARD, G. V. and DOUGLAS, R. N. (This issue). Is the Engram of Kindling Model the Engram of Long-Term Memory? Canadian Journal of Neurological Sciences.

GUNNE, L. M. and REIS, D. J. (1963). Changes in Brain Catecholamines Associated with Electrical Stimulation of Amygdaloid Nucleus. Life Science, 11: 804-809.

LIDSKY, T. L., LEVINE, M. S., KREINICK, C. J. and SCHWARTZBAUM, J. S. (1970). Retrograde Effects of Amygdaloid Stimulation on Conditioned Suppression (CER) in Rats. Journal of Comparative and Physiological Psychology, 73: 135-149.

NAKAO. H. (1962). Spread of Hippocampal Afterdischarge and the Performance of Switch-Off Behavior Motivated by Hypothalamic Stimulation in Cats. Folia Psychiatrica et Neurologica Japonica, 16: 168-180.

NAKAO, H. (1967). Facilitation and Inhibition in Centrally Induced Switch-Off Behavior in Cats. Progress in Brain Research, 27: 128-143. Elsevier Publishing Co., Amsterdam.

McINTYRE, D. C. (1970). Differential Amnestic Effect of Cortical vs. Amygdaloid Elicited Convulsions in Rats. Physiology and Behavior, 5: 747-753.

McINTYRE, D. C. and REICHERT, $H$. (1971). State-Dependent Learning in Rats Induced by Kindled Convulsions. Physiology and Behavior, 7: 15-20.

MCINTYRE, D. C. and MOLINO, A. (1972). Amygdala Lesions and CER Learning: Long-Term Effect of Kindling. Physiology and Behavior, 8: 1055-1058.

SEINO, M. and WADA, J. A. (1964). Chronic Focal Cortical Lesions and Behavior: Comparison of Behavioral Performance in Monkeys with Either Destructive or Epileptogenic Unilateral Lesion. Epilepsia, 5: 321-333.

WADA, J. A. (1964). Longitudinal Analysis of Chronic Epileptogenic Brain Process. Epileptology. (Ed.) Wada, T., p. 426-453, Igakushoin, Tokyo.
WURTZ, R. H. and OLDS, J. (1963). Amygdaloid Stimulation and Operant Reinforcement in the Rat. Journal of Comparative and Physiological Psychology, 56: 941-949.

YOSHII, N. and YAMAGUCHI, Y. (1963). Conditioning of Seizure Discharges with Electrical Stimulation of the Limbic Structures in Cats. Folia Psychiatrica et Neurologica Japonica, 17: 276-143.

\section{(1) CLINICAL IMPLICATIONS}

ANDO, M. (1956). Clinical EEG of Epileptic Psychosis (Japanese). Psychiatrica et Neurologica Japonica, 58: 277-292.

ARAKI, T., YASUDA, Y., AOKI, N. and NIHON MATSU, S. (1958). Spontaneous Epileptic Seizure Induced by Electroshock Treatment. (Japanese). Brain and Nerve, 10: $541-547$.

ASSAEL, M. I., HALPERIN, B. and AL. PERN, S. (1967). Centrencephalic Epilepsy Induced by Electrical Convulsive Treatment. Electroencephalography and Clinical Neurophysiology, 23: 193-196.

BLUMENTHAL, I. J. (1953). Electroencephalographic Survey of Mentally III Epileptic Veterans. Journal of Nervous and Mental Diseases, 118: 204-222.

BLUMENTHAL, I. J. (1955). Spontaneous Seizures and Related Electroencephalographic Findings Following Shock Therapy. Journal of Nervous and Mental Diseases, 122: $581-588$.

FERRARO, A. L., ROIZIN, L. and HELFAND, M. (1946). Morphologic Changes in Brain of Monkeys Following Convulsions Electrically Induced. Journal of Neuropathology and Experimental Neurology, 5: 285-308.

FOLKSON, A. (1947). Status Epilepticus After Electric Convulsion Therapy. British Medical Journal, 2: 335.

FOSS, L. (1954). Epilepsy as Sequel of Prolonged Shock Therapy in Schizophrenia. Tidsskr. norske, laegefor, 74: 236-239.

GLOOR, P. (1972). Temporal Lobe Epilepsy: Its Possible Contribution to the Understanding of the Functional Significance of the Amygdala and of its Interaction with Neocortical-Temporal Mechanisms. The Neurobiology of Amygdala (Ed.) Eleftheriou, B.E., 423-457, New York.
GODDARD, G. V. (1971). The Kindling Effect: A Precautionary Note on Therapeutic Applications of Localized Brain Stimulation. Reynolds, D. V. and Sjoberg, A. E. (Eds.) Neuroelectric Rescarch, Electroprotheses, Electroanesthesia and Nonconvulsive Electrotherapy. Charles C. Thomas, Springfield, pp. 37-39.

HEATH, R. G., MONROE, R. R. and MICKLE, W. A. (1955). Stimulation of the Amygdaloid Nucleus in Schizophrenic $\mathrm{Pa}$ tients. American Journal of Psychiatry, 111: 862-863.

HEILBRUNN, G. and WEIL, A. (1942). Pathologic Changes in Central Nervous System in Experimental Electric Shock. Archives of Neurology and Psychiatry, 47: 918-930.

KLOTZ, M. (1955). Serial Electroencephalographic Changes Due to Electrotherapy. Diseases of the Nervous System, 16: $120-121$.

KOHLER, W., MEYER, F. and BLEUDINGER, G. (1954). Krampfbehandlung und Spontan Epileptische Anfälle, Nervenarzt, 25: 225-232.

LEVY, N. A., SEROTA, H. M. and GRINKER, R. R. (1942). Disturbances in Brain Function following Convulsive Shock Therapy: Electroencephalographic and Clinical Studies. Archives of Neurology and Psychiatry, 47: 1009-1029.

PACELLA, B. L. and BARRERA, E. S. (1945). Spontaneous Convulsions Following Convulsive Shock Therapy. American Journal of Psychiatry, 101: 783-788.

PINEL, J. P. J., MUCHA, R. F. and VAN OOT, P. H. (This issue). Generality of the Kindling Phenomenon: Some Clinical Implications. Canadian Journal of Neurological Sciences.

SHIOIRI, E. (1943). Schizophrenic Patients Developing Epileptic Seizure following Electroshock Treatment (Japanese). Psychiatria et Neurologica Japonica, 47: 343.

SHIOIRI, E. (1943). Epileptiform Attack Following Electroshock Treatment. Psychiatria et Neurologica Japonica, 47: 759.

STEVENS, J. R., MARK, V. H., ERVIN, $F$., PACHEKO, $P$. and SUEMATSU, $K$. (1969). Deep Temporal Stimulation in Man: Long Latency, Long Lasting Psychological Changes. Archives of Neurology, 21: 157-169. 